\title{
Analysis of Increasing Taxpayer Compliance Through Awareness and Tax Sanctions in Medan City
}

\author{
Johnson ${ }^{1}$, Muammar Rinaldi ${ }^{2, *}$ \\ ${ }^{1}$ Faculty of Economics, Universitas Negeri Medan, Indonesia \\ ${ }^{2}$ Eka Prasetya College of Economics, Indonesia \\ *Corresponding author. Email: muammar@ekaprasetya.ac.id
}

\begin{abstract}
This study aims to determine the effect of Taxpayer Awareness and Tax Sanctions on Taxpayer Compliance in Individual Taxpayers in Medan City. The population in this study is an individual taxpayer in the city of Medan. The results of the research analysis showed that Taxpayer Awareness and Tax Sanctions significantly influence the Compliance of Taxpayers in Individual Taxpayers in the city of Medan. The results of this study are supported by the value of $\mathrm{R}$ square (R2) which means that the Taxpayer Awareness and Tax Sanctions has an effect on the Compliance of Taxpayers on Individual Taxpayers in the city of Medan. While the remaining is influenced by other factors originating from outside this research model such as tax knowledge, tax audits, and tax amnesty.
\end{abstract}

Keywords: Taxpayer Awareness, Tax Sanctions, Taxpayer Compliance

\section{INTRODUCTION}

Indonesia is a developing country that has a variety of rich and abundant resources and has good potential. The source of Indonesian revenue is divided into two, namely domestic revenue and foreign revenue, and tax revenue is one of the sources of state revenue. However, the achievement of tax revenues planned by the government has not yet got maximum results. This is due to the low number of registered taxpayers in Indonesia and the lack of public compliance who thinks that tax returns through the construction of good public infrastructure and service facilities have not been implemented evenly. So that people tend to avoid paying taxes starting by not registering themselves as taxpayers. The measure of the level of tax compliance can be seen from whether the taxpayer has submitted a notification letter or not, be it an annual tax return or a periodic tax return.

Tax revenue cannot only rely on the government but also requires an active role from the taxpayers themselves. Efforts made by the government such as reforming the tax system have also been carried out. Previously, Indonesia's tax collection system was the official assessment system and in 1983, this system had changed to a self-assessment system. Taxpayers have the obligation to have a Taxpayer Identification Number if it meets subjective and objective requirements based on statutory provisions. Although many taxpayers already have Taxpayer Identification Numbers, there are still many taxpayers who do not carry out their obligations as taxpayers who are compliant to pay taxes. Ownership of a Taxpayer Identification Number must be able to provide benefits so that it becomes one of the factors that can affect taxpayer compliance. The government must also do a lot of socialization so that taxpayers can report taxes that should be given to the government without reducing or keeping it for themselves. The enactment of the self-assessment system makes the public have an active role in fulfilling their obligations by increasing the awareness of taxpayers to have an independent attitude in knowing, recognizing, appreciating, and complying with the provisions of applicable tax regulations and having the seriousness and desire to pay and report their taxes. The height of the taxpayer is the most important factor in implementing the self-assessment system. Taxpayer awareness is a sense that arises from within the taxpayer for his obligation to pay taxes sincerely without any element of compulsion. The higher the level of Taxpayer Awareness, the better the understanding and implementation of tax obligations so that it can increase taxpayer compliance.

\section{THEORETICAL FRAMEWORK}

Tax payer compliance can also be improved through the imposition of tax sanctions for taxpayers who do not fulfill their tax obligations, tax sanctions are expected to 
have a positive impact so that taxpayers comply with applicable tax regulations. Thus, taxpayers will fulfil their tax obligations if they view that tax sanctions are more detrimental to them. The firmness of the Directorate General of Taxes in applying sanctions to taxpayers who do not comply is needed to form taxpayer compliance behavior.

Tax compliance is the obedience of taxpayers in implementing applicable taxation provisions [1]. Compliant taxpayers are taxpayers who comply with tax obligations following statutory provisions. Taxpayer awareness is a condition in which taxpayers understand and understand the meaning, function, and purpose of paying taxes to the state [1].

Tax sanctions as stipulated in Article 39 of Law Number 28 of 2007 concerning the Third Amendment to Law Number 6 of 1983 concerning General Provisions and Tax Procedures that for taxpayers who deliberately do not register themselves, or abuse or use without the right of the NPWP, the inauguration of PKP, so that it can cause losses to state revenues, is punishable by imprisonment for a minimum of 6 (six) months and a maximum of 6 (six) years and a fine of at least 2 (two) times the amount of unpaid or underpaid tax [2].

The following is testing the research hypothesis:

H1. It is suspected that there is the influence of Taxpayer Awareness on Taxpayer Compliance with Individual Taxpayers in Medan City.

H2. It is suspected that there is the influence of Tax Sanctions on Taxpayer Compliance with Individual Taxpayers in Medan City.

H3. It is suspected that there is the influence of Taxpayer Awareness and Tax Sanctions on Taxpayer Compliance with Individual Taxpayers in Medan City.

\section{RESEARCH METHODOLOGY}

The type of data used in this research is quantitative data, where the data in this study will present the results of the questionnaire for each variable studied. The quantitative data is in the form of statements that are scaled on an interval scale. The population in this study is an individual taxpayer who is registered in the city of Medan.

The technique of collecting data through questionnaires is done by asking questions to parties related to the problem under study and using an Interval scale to make measurements.

The data analysis model used in this research is multiple regression analysis model. Researchers use multiple linear regression because this model is useful for looking for the effect of two or more independent variables on the existing dependent variable. The multiple regression equation model is:
$Y=a+b 1 X 1+b 2 X 2+e$
Information:
Y : Taxpayer Compliance
a : Constant
b : Independent Variable Regression Coefficient
X1 : Taxpayer Awareness Variable
X2 : Tax Sanctions Variable
e : Standard Error

\section{RESULTS}

\subsection{Respondent Characteristics}

The respondent's description is a description of the unit of analysis/observation under study which includes the characteristics or profile of the respondents obtained from the results of questionnaire data processing. The results of data collection were carried out by distributing questionnaires to 32 respondents who have a Taxpayer Identification Number in Medan City and the characteristics of respondents based on the dominant gender are male, the age of the dominant respondent is under 30 years old, the last education of the dominant respondent is SMA or equivalent.

\subsection{Validity Test and Reliability Test}

The results of the reliability tests will be presented in the Table 1.

Table 1. Reliability Test

\begin{tabular}{|c|c|c|}
\hline Variable & items & Cronbach's Alpha \\
\hline $\mathrm{X} 1$ & 14 & 0.782 \\
\hline $\mathrm{X} 2$ & 18 & 0.787 \\
\hline $\mathrm{Y}$ & 14 & 0.823 \\
\hline
\end{tabular}

From the results of the table above, the r-count value of each statement item foreach variable obtained is above the $t$ table (0.3494) so that it can be said that the statement used is said to be valid.

\subsection{Classic assumption test}

\subsubsection{Normality test}

The normality test aims to test whether in the regression model confounding or residual variables have a normal distribution. There are two ways to detect whether the residuals are normally distributed or not, namely by graph analysis and statistical tests. 
Based on the Table 3, it can be seen that the correlation value for the Taxpayer Awareness and Tax Sanctions variables has a tolerance value $(0.996)>0.10$ and a VIF value $(1.004)<10$ so it can be concluded that based on the picture on Figure 1, it can be seen that the data spreads around the diagonal line and follows the direction of the diagonal line or the histogram graph

Table 2. Component Matrix Values ${ }^{\alpha}$

\begin{tabular}{|c|c|c|}
\hline Variable & Statement & $r_{\text {count }}$ \\
\hline \multirow[t]{14}{*}{ Taxpayer Awareness $\left(\mathrm{X}_{1}\right)$} & Statement-1 & 0.367 \\
\hline & Statement-2 & 0.580 \\
\hline & Statement-3 & 0.435 \\
\hline & Statement-4 & 0.609 \\
\hline & Statement-5 & 0.528 \\
\hline & Statement-6 & 0.640 \\
\hline & Statement-7 & 0.410 \\
\hline & Statement-8 & 0.444 \\
\hline & Statement-9 & 0.580 \\
\hline & Statement-10 & 0.650 \\
\hline & Statement-11 & 0.628 \\
\hline & Statement-12 & 0.384 \\
\hline & Statement-13 & 0.517 \\
\hline & Statement-14 & 0.381 \\
\hline \multirow[t]{18}{*}{ Tax Sanctions $\left(\mathrm{X}_{2}\right)$} & Statement-1 & 0.359 \\
\hline & Statement-2 & 0.526 \\
\hline & Statement-3 & 0.639 \\
\hline & Statement-4 & 0.471 \\
\hline & Statement-5 & 0.385 \\
\hline & Statement-6 & 0.637 \\
\hline & Statement-7 & 0.622 \\
\hline & Statement-8 & 0.451 \\
\hline & Statement-9 & 0.413 \\
\hline & Statement-10 & 0.537 \\
\hline & Statement-11 & 0.383 \\
\hline & Statement-12 & 0.576 \\
\hline & Statement-13 & 0.422 \\
\hline & Statement-14 & 0.376 \\
\hline & Statement-15 & 0.405 \\
\hline & Statement-16 & 0.404 \\
\hline & Statement-17 & 0.374 \\
\hline & Statement-18 & 0.365 \\
\hline \multirow[t]{14}{*}{ Taxpayer Compliance (Y) } & Statement-1 & 0.691 \\
\hline & Statement-2 & 0.555 \\
\hline & Statement-3 & 0.582 \\
\hline & Statement-4 & 0.512 \\
\hline & Statement-5 & 0.677 \\
\hline & Statement-6 & 0.533 \\
\hline & Statement-7 & 0.512 \\
\hline & Statement-8 & 0.600 \\
\hline & Statement-9 & 0.353 \\
\hline & Statement-10 & 0.399 \\
\hline & Statement-11 & 0.388 \\
\hline & Statement-12 & 0.654 \\
\hline & Statement-13 & 0.631 \\
\hline & Statement-14 & 0.567 \\
\hline
\end{tabular}

shows a normal distribution pattern, so regression is considered to fulfil the assumption of normality.

\subsubsection{Multicollinearity Test}

The results for multicollinearity testing can be seen in the Taxpayer Awareness and Tax Sanctions variables do not have multicollinearity symptoms.

Table 3. Multicollinearity Test

\begin{tabular}{|l|c|c|}
\hline \multirow{2}{*}{ Model } & \multicolumn{2}{c|}{ Collinearity Statistics } \\
\cline { 2 - 3 } & Tolerance & VIF \\
\hline 1. (Constant) & & \\
\hline Taxpayer Awareness & 0.996 & 1.004 \\
\hline Tax Sanctions & 0.996 & 1.004 \\
\hline
\end{tabular}

Based on the table above, a multiple linear regression equation is obtained where if the value of the independent variable (X1), namely Taxpayer Awareness, and the variable (X2), namely Tax Sanctions, has a value of 0 , then Taxpayer Compliance is fixed at 1.657. Every increase in the aspect of Taxpayer Awareness (X1) by 1 unit, then Taxpayer Compliance will increase by 0.393 .

Every increase in the aspect of Tax Sanctions (X2) by 1 unit, the Taxpayer Compliance will increase by 0.390 .

\subsubsection{Hypothesis testing}

a. Partial Testing (t-test)

The results of partial hypothesis testing (t-test) can be seen in the table below as Table 5.

Table 4. Partial Test

\begin{tabular}{|l|c|c|}
\hline \multicolumn{3}{|c|}{ Coefficients $^{\mathbf{\alpha}}$} \\
\hline Model & $\mathrm{t}$ & Sig. \\
\hline 1. (Constant) & 0.122 & 0.904 \\
\hline Taxpayer Awareness & 2.268 & 0.031 \\
\hline Tax Sanctions & 2.591 & 0.015 \\
\hline
\end{tabular}

a. Dependent Variable: Taxpayer Compliance

Source: Results of data processing, 2020

The Taxpayer Awareness Variable (X1) has a count (2.268)> t table (2.04227) with a significant level of $0.031<0.05$ and the Tax Sanctions Variable (X2) has a count (2.591)> t table (2.04227) with a significance of $0.015<0.05$, so it can be concluded that there is a partially significant influence between Taxpayer Awareness and Tax Sanctions on Taxpayer Compliance at Pizza Boy Adam Malik Medan.

\subsubsection{Simultaneous Test (F-Test)}

The results of simultaneous hypothesis testing (FTest) can be seen in the table below as follows:

Based on Table, it can be seen that the value of Fcount (6.300)> F-table (3.33) with a significance of 0.00 $<0.05$ so that it can be concluded that there is a significant influence between Taxpayer Awareness and Tax 
Sanctions simultaneously on Taxpayer Compliance with Individual Taxpayers. in Medan City

\subsubsection{Determination Coefficient (R2)}

The test results of the coefficient of determination (R2) can be seen in the table below as follows:

Based on Table above, it can be seen that the value of $\mathrm{R}$ Square (R2) or the coefficient of determination obtained is 0.303, meaning that the Taxpayer Compliance variable can be explained by the Taxpayer Awareness and Tax Sanctions variables of $30.3 \%$ while the remaining $69.7 \%$ is influenced by factors- Other factors that come from outside this research model such as knowledge of taxation, tax audits, tax authorities, level of understanding of taxation and tax amnesty.

\section{DISCUSSION OF RESEARCH RESULTS}

\subsection{The Influence of Taxpayer Awareness on Taxpayer Compliance}

Based on the partial test results regarding Taxpayer Awareness of Taxpayer Compliance, Taxpayer Awareness has a significant effect on Taxpayer Compliance with Individual Taxpayers in Medan City. Based on this, hypothesis 1 (first) in this study is accepted.

The results of this study are in line with previous research conducted by [3] which in their research states that Taxpayer Awareness has a positive influence on

Table 5. Simultaneous Test

\begin{tabular}{|l|c|c|}
\hline \multicolumn{3}{|c|}{ ANOVA $^{\alpha}$} \\
\hline Model & F & Sig. \\
\hline 1. Regression & 6300 & $.005^{\text {b }}$ \\
\hline Residual & & \\
\hline Total & & \\
\hline
\end{tabular}

a. Dependent Variable : Taxpayer Compliance

b. Predictors: (Constant), Tax Sanction, Taxpayer Awareness Source: Results of data processing, 2020

Taxpayer Compliance [4] who in their research state that Taxpayer Awareness has a significant effect on Taxpayer Compliance [5], who in her research stated that Taxpayer Awareness has a significant effect on Taxpayer Compliance [6].

\subsection{The Effect of Tax Sanctions on Taxpayer Compliance}

Based on the partial test results regarding Tax Sanctions on Taxpayer Compliance, Tax Sanctions have a significant effect on Taxpayer Compliance with Individual Taxpayers in Medan City. Based on this, hypothesis 2 (second) in this study is accepted.

The results of this study are in line with previous research conducted by [1], which in their research stated that Tax Sanctions have a significant effect on Taxpayer Compliance [4], who in their research stated that Tax Sanctions have a significant effect on Taxpayer Compliance [5], who in her research stated that Tax Sanctions have a significant effect on Taxpayer Compliance [6].

Table 6. Determination Coefficient Test

\begin{tabular}{|c|c|c|c|}
\hline \multicolumn{4}{|c|}{ Model Summary $^{\mathbf{b}}$} \\
\hline Model & $\mathrm{R}$ & R Square & $\begin{array}{c}\text { Adjusted R } \\
\text { Square }\end{array}$ \\
\hline 1. & $0.550^{\mathrm{a}}$ & .303 & .255 \\
\hline
\end{tabular}

\subsection{Effect of Taxpayer Awareness and Tax Sanctions on Taxpayer Compliance}

Based on the simultaneous test results on Taxpayer Awareness and Tax Sanctions on Taxpayer Compliance, Taxpayer Awareness and Tax Sanctions have a significant effect on Taxpayer Compliance with Individual Taxpayers in Medan City. Based on this, hypothesis 3 (third) in this study is accepted.

The results of this study are in line with previous research conducted [3], who in her research stated that Tax Sanctions have a significant effect on Obligatory Compliance [1].

\section{CONCLUSIONS RECOMMENDATIONS}

AND

\subsection{CONCLUSION}

Based on the results and discussion of the research, the authors made the following conclusions:

a. The results of this study state that the effect of Taxpayer Awareness and Tax Sanctions on Taxpayer Compliance as indicated by the results of multiple linear analysis means that any increase in the variable aspects of Taxpayer Awareness and Tax Sanctions, Taxpayer Compliance will increase.

b. The t-test results show that Taxpayer Awareness partially has a significant effect on Taxpayer Compliance with Individual Taxpayers in Medan City.

c. The results of the t-test show that tax sanctions partially have a significant effect on taxpayer compliance with individual taxpayers in Medan.

d. The F-Test results show that Taxpayer Awareness and Tax Sanctions simultaneously have a significant effect on Taxpayer Compliance with Individual Taxpayers in Medan City.

e. The coefficient of determination test results show that Taxpayer Awareness and Tax Sanctions can explain the relationship with Taxpayer Compliance. In addition to the Taxpayer Awareness and Tax 
Sanctions variables, Taxpayer Compliance can be influenced by other variables not examined in this study, such as knowledge of taxation, tax auditing, and tax amnesty.

\subsection{MANAGERIAL IMPLICATIONS}

Based on the analysis that the author has done, the implications that can be given to the company are as follows:

1. The Tax Office must pay attention to Taxpayer Awareness of Taxpayer Compliance:

a. Tax revenue has an effect on state development funds because tax revenue is the largest state income in Indonesia. Therefore, the government continues to strive to increase tax revenue so that development funds can run smoothly.

b. Taxpayers pay taxes because of self-awareness because self-awareness makes taxpayers know and understand the benefits of paying taxes. Taxpayers who are aware of course will pay their taxes in accordance with the provisions of the applicable laws and regulations.

2. Tax Sanctions at the Tax Service Office need to be maintained, so the Tax Service Office must maintain:

a. Taxpayers will be subject to sanctions if they do not register. This applies to people who have met the requirements as tax subjects or tax objects. If the person has met these requirements, the person is required to report himself as a taxpayer by obtaining a Taxpayer Identification Number (NPWP).

b. Taxpayers may not use the Taxpayer Identification Number and Taxable Entrepreneur of another person without the person's permission, because this could make taxation sanctions, not on target. If it is not treated properly, then the sanctions given will result in confusion.

\subsection{ACADEMIC ADVICE}

Suggestions that can be given to academics are:

a. For the academic community, researchers hope that this research can add insight regarding the factors that affect Taxpayer Awareness and Tax Sanctions and Individual Taxpayer Compliance and as reference material.

b. For future researchers, it is expected to expand the variables in the selected taxation sector in order to produce more accurate research at the Tax Office.

c. For the Tax Service Office, this research is expected to provide input to the Tax Service Office in an effort to awaken and provide appropriate tax sanctions for taxpayers who are not obedient in order to fulfil their obligations as taxpayers.

\section{REFERENCES}

[1] Rahayu, Siti K., Perpajakan Konsep dan Aspek Formal. Bandung: Rekayasa Sains, 2017.

[2] Waluyo, Perpajakan Indonesia. Jakarta: Salemba Empat, 2017.

[3] Harjo, Dwikora. Perpajakan Indonesia Sebagai Materi Perkuliahan di Perguruan Tinggi Edisi 2. Jakarta: MitraWacana Media, 2019.

[4] Herlina, Vivi. Panduan Praktis Mengolah Data Kuesioner. Jakarta: PT Elex Media Komputindo, 2019.

[5] Lubis, Rahmat H., Pajak Penghasilan Teori, Kasusdan Aplikasi. Yogyakarta: C. V ANDI OFFSET, 2018.

[6] Malik, Nazaruddin, dkk. Membangun Ekonomi Nasional yang Kokoh. Malang: Universitas Muhammadiyah Malang, 2015. 